TECHNICAL TRANSACTIONS 4/2018

CHEMISTRY

DOI: $10.4467 / 2353737$ XCT.18.057.8369 SUBMISSION OF THE FINAL VERSION: $25 / 3 / 2018$

\title{
Dominika Misiura
}

Tomasz M. Majka (tomasz.majka@pk.edu.pl)

Department of Chemistry and Technology of Polymers, Cracow University of Technology

\section{AN OVERVIEW ON OBTAINING FOAMED PET BY REACTIVE EXTRUSION}

PRZEGLĄD SPOSOBÓW POZYSKIWANIA SPIENIONEGO PET

METODĄ REAKTYWNEO WYTEACZANIA

\begin{abstract}
Many methods are used to obtain functional polymer foams. This review focuses on reactive extrusion of poly(ethylene terephthalate). This process is based on the reaction between PET and the appropriate blowing agent. The next step is the creation of foam by closing gas cells in the polymer matrix. This method of modification allows material with higher molecular weight to be obtained and, therefore, higher melt strength. The use of different chemical modifiers and their concentration influences properties of created foam. The enhanced features of foamed PET allow it to be used in many areas of application such as transport, construction or general industry. Another big advantage of this technique is the possibility of using recycled materials as the source of PET.
\end{abstract}

Keywords: PET; Foams; Reactive extrusion

\section{Streszczenie}

Do uzyskania funkcjonalnych pianek polimerowych stosuje się wiele metod. Niniejszy przegląd koncentruje się na reaktywnym wytłaczaniu poli(tereftalanu etylenu). Proces ten opiera się na reakcji pomiędzy PET i odpowiednim środkiem porotwórczym. Następnym krokiem jest wytworzenie piany przez zamknięcie komórek gazu w matrycy polimerowej. Ten sposób modyfikacji pozwala na uzyskanie materiału o wyższej masie cząsteczkowej. Zastosowanie różnych modyfikatorów chemicznych i ich koncentracja wpływa na właściwości otrzymanej piany. Udoskonalone właściwości spienionego PET pozwalają na stosowanie go w wielu obszarach, takich jak transport, budownictwo lub przemysł. Inną dużą zaletą tej techniki jest możliwość wykorzystania materiałów pochodzących z recyklingu jako źródła PET. 


\section{Introduction}

Nowadays it's difficult to imagine living without synthetic organic polymers; the growing scale of their production is remarkable. Since the early 50's, plastic materials have managed to surpass other man-made materials. For many years, the largest area of application of polymer materials has been the packaging sector, accounting for $34.9 \%$ of the total demand for plastics. The packaging industry is dominated by bottles, films, bags and various types of containers made of polyethylene, polypropylene, polystyrene and polyethylene terephthalate (PET). Most monomers used in the production of these compounds are not biodegradable, thus most of these materials are accumulated in the environment. The large scale of production leads to many problems related to waste management; since 2015 almost $6300 \mathrm{Mt}$ of plastic waste have been generated. Only $9 \%$ of that has been recycled and over $79 \%$ has been accumulated. These amounts of misused products are pushing scientists towards looking for ways to reuse them. The disposal of polymeric waste is associated with the need to give the products obtained from such waste attractive features. On the basis of global trends, it can be concluded that mechanical recycling is the recommended way to reduce the share of waste accumulated in landfills [1].

The repeated processing of polymeric materials, however, is associated with the danger of their thermo-mechanical degradation and consequently with reduction of strength parameters. Improvements in properties can be obtained by mixing recycled materials with other polymers, although it's required to use the properly selected components. Another use of polymer waste is the production of porous materials, which in comparison to solid materials are less dense, and have better thermal insulation properties and greater vibration damping capacity. These features make the materials of cellular structure necessary for the construction, automotive and packaging industries. Factors limiting the development of porous materials are lower mechanical strength, complex processing and ecological considerations [2].

One of the polymers widely used in the production of bottles, containers, sheets, and fibres is poly(ethylene terephthalate). PET, as a thermoplastic polymer, is usually processed by extrusion or injection moulding; its thermal stability allows efficient and stable production of high-quality materials to be established. Another big advantage of PET processing technology is its recyclability. Due to the high annual consumption of products made of PET, it's important to find efficient ways of developing new products from waste materials. During the recycling processes, PET undergoes chemical, mechanical, and thermal degradation, which limits its use in many applications by lowering the molecular weight of the polymer and mechanical properties. Because of the low cost and low performance applications of the recycled material, at present, the widely accepted opinion is that the waste-PET mechanical recycling without a structural up gradation is not an efficient procedure [3].

This article presents an overview on the structural up-grading of PET by foaming it during reactive extrusion - a procedure considered efficient for the enhancement of its properties. 


\section{Reactive extrusion of PET}

Reactive processing of poly(ethylene terephthalate) in order to extend macromolecular chains takes place in the same equipment as the melting process, at the polymer's melting point. This method bears both advantages of low costs and simple preparation. During this process a multifunctional compound reacts with PET nucleophilic end-groups to re-join polymer chains destroyed during its processing or use. Usually, by reactive processing, it is possible to obtain mechanical and rheological properties equal or higher than those of virgin polymers. That's why the reactive processing of PET is seen as a chance to add value to the post-consumption of polymers and to create products with added value. The reactively extruded material can be used without physical modification in main applications as bottles and foam sheets. The process of reactive extrusion is most commonly carried out at a temperature of $270-280^{\circ} \mathrm{C}[2,3]$.

\subsection{Chain extenders}

The chain extenders are mono-, di- or poly-functional organic compounds with low molecular weight $(\mathrm{Mn}<3000)$. The typical extender functional groups are hydroxyl, carboxyl, anhydride, amine, epoxy, etc. Depending on its own chemical structure, each compound yields typical extension reactions [4].

\subsubsection{Pyromellitic dianhydride}

The modifying agents most often used are those belonging to the group of di-functional chain extenders, like bisepoxy compounds or diisocyanates. One of the widely used compounds is pyromellitic dianhydride (PMDA), which does not form by-products and leads to strongly cross-linked PET. PMDA is a tetra functional modifier that is thermally stable. It is efficient in proportion a of $0.2-0.3 \%$ and raises the viscosity by depending on the reaction with PET hydroxide groups (Fig. 1) [5,7].

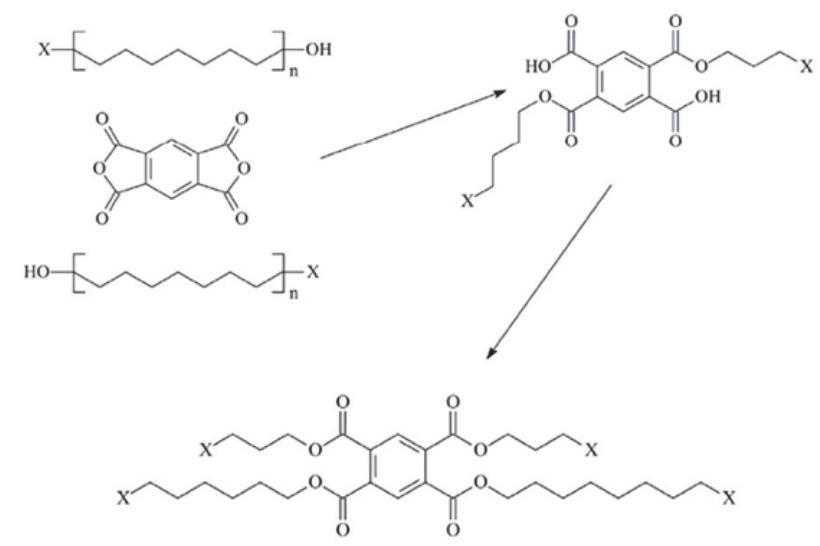

Fig. 1. PET chain extension with PMDA [5] 


\subsubsection{Epoxy compounds}

Epoxy resins like tetraglycidyl diamino diphenyl methane (TDDM) (Fig. 2) esterify carboxyl groups and etherify hydroxyl groups at the end of the chain of PET macromolecules. In both reactions, secondary hydroxyls are formed that can react later with the carboxyl or epoxy groups (Fig. 3). This can cause the formation of branched structures. It is efficient in a proportion of $0.43 \%[5,8]$.

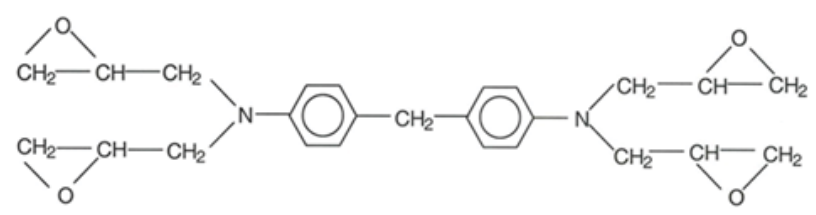

Fig. 2. Structure of tetraglycidyl diamino diphenyl methane [5]

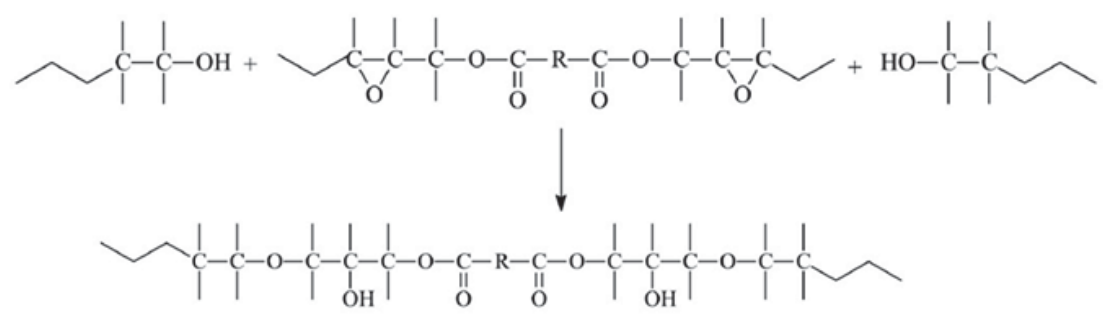

Fig. 3. PET chain extension with diepoxide [5]

\section{Foaming process}

The cellular structure can be produced in polymers by continuous or batch processes by means of solid, liquid or gaseous foaming agents. However, in any case the processes leading to the desired foaming capacities depend on the type of material used, the technology selected, and the parameters of processing. Their correct choice and precision are a challenge for many researchers [6].

In this process the following stages are distinguished:

- dissolving the gas in a polymer obtained under high pressure (solid polymer) or high temperature and pressure (polymer in the form of a liquid);

- nucleation of the gaseous phase germs in the system as a result of rapid change of the thermodynamic state of the material due to decompression and temperature change;

- the increase in the pore size and amount depends on the content of the foaming agent, the process parameters and the properties of the material;

- fixation of the structure by cooling to a temperature lower than the glass transition temperature of the polymer or its crosslinking $[6,7]$. 
Depending on the type of polymer used, rigid or soft foams are obtained, and from the point of view of type, quantity and pore size, the porous materials are classified in terms of specific weight into foams of high $\left(>240 \mathrm{~kg} / \mathrm{m}^{3}\right)$, intermediate $\left(240-1.6 \mathrm{~kg} / \mathrm{m}^{3}\right)$ and low $\left(<1.6 \mathrm{~kg} / \mathrm{m}^{3}\right)$ density, and according to the type of pores, into closed or opened pores [6].

The selection of parameters of the foaming process is related to the type of ingredients used. A very important parameter is temperature, especially when chemical foaming agents are used; the temperature must be high enough to cause decomposition of the gaseous products necessary to produce the porous structure in the melted polymer, but it must not be too high to cause degradation of the plastic material. The most commonly used temperature for PET foaming is $270-280^{\circ} \mathrm{C}$ [ 7 ].

PET as a foamed material possesses few limitation characteristics like unsatisfying viscosity that causes the collapsing of the foam structure during the stabilization phase of foam production. It's important to be aware of the need to increase polymer viscosity by the time of the end of foam rising. While keeping in mind the possibilities of increasing polymers molecular mass and viscosity by its reactive extrusion, it seems obvious to connect those two processes in order to obtain a high value material [8].

The agents most often used in PET foaming are chemical compounds like Hydrocerol CT534 or carbon dioxide used under high pressure [7].

The use of chemical foaming agents leads to the creation of the PET foam by decomposition of the agent. The gas produced from the blowing agent is dissolved in the polymer and then released to create separate phases. This method makes it possible to produce porous material with a cell size of $100-200 \mu \mathrm{m}$ [8].

Using $\mathrm{CO}_{2}$ as a PET foaming agent is popular because of its environmental friendly properties and high solubility in the polymer (when compared with other gases). Using a different pressure on the foamed material allows the concentration levels of the dissolved gas to be controlled and, therefore, the size of the pores created [8].

\section{Conclusions}

In the times when environmental safety is being more and more in danger, scientists are obliged to look for new ways of using waste materials. Recycling PET and turning it into a new, high value foam material has been the topic of interest of this article. As was described, the reactive extrusion of foamed PET leads to obtaining of a material characterized by better properties than the initial polymer. Even though it seems that the production of foamed PET has been completely studied, there's still plenty of room for improvements in this topic. The more the particular mechanisms of every step of production are examined, the more control over the final product will be obtained.

The main aim of this review is to show that the use of only two steps - chain extension and foaming, leads to the creation of a highly useful product with possibilities of use in many branches of industry, like construction, automotive, and packaging. 


\section{References}

[1] Geyer, Jambeck, Production, use, and fate of all plastics ever made, Law Sci. Adv. 2017, 3.

[2] Raffa, Coltelli, Savi,Bianch, Castelvetro, Chain extension and branching of poly (ethylene terephthalate) (PET) with di- and multifunctional epoxy or isocyanate additives: An experimental and modelling study, Reactive \& Functional Polymers, 2012, 72.

[3] Tavares, Silva, Lima, Andrade, Canedo, Chain extension of virgin and recycled polyethylene terephthalate, Polymer Testing, 2016, 50.

[4] Awaja, Daver, Kosior, Cser, The Effect Of Chain Extension On The Thermal Behaviour And Crystallinity Of Reactive Extruded Recycled Pet, Journal of Thermal Analysis and Calorimetry, 2004, 78.

[5] Dimonie, Socoteanu, Pop, Fierascu, Fierascu, Petrea, Zaharia, Petrache, Material Recycling - Trends and Perspectives: Overview on Mechanical Recycling by Chain Extension of POSTC-PET Bottles, InTech, 2012.

[6] Kozłowski, Kozłowska, Frąckowiak, Materiaty polimerowe o strukturze komórkowej, Polimery, 2010, 55.

[7] Maio, Coccorullo, Montesano. Incarnato, Chain Extension and Foaming of Recycled PET in Extrusion Equipment, Macromol. Symp., 2005, 228.

[8] Japon, Leterrier, Manson, Recycling of Poly(Ethylene Terephthalate) Into Closed-Cell Foams, Polymer Engeneering and Science, 2000, 40. 